\title{
Evaluation of glutathione S-transferase P1 genetic variants affecting type-2 diabetes susceptibility and glycemic control
}

\author{
Mahmoud A. Amer ${ }^{1}$, Maivel H. Ghattas ${ }^{2}$, Dina M. Abo-ElMatty ${ }^{3}$, Soad H. Abou-El-Ela ${ }^{3}$
}

1Department of Pharmacology, Faculty of Pharmacy, Sinai University, El-Arish, Egypt 2Department of Medical Biochemistry, Faculty of Medicine, Suez Canal University, Ismailia, Egypt

3Department of Biochemistry, Faculty of Pharmacy, Suez Canal University, Ismailia, Egypt

Submitted: 4 September 2011

Accepted: 5 December 2011

Arch Med Sci 2012; 8, 4: 631-636

DOI: 10.5114/aoms.2012.30286

Copyright @ 2012 Termedia \& Banach

\section{Abstract}

Introduction: Type 2 diabetes mellitus (T2DM) is associated with increased production of reactive oxygen species and a reduction in antioxidant defenses leading to oxidative stress. Glutathione S-transferases (GSTs) modulate oxidative stress. The present cross-sectional study was aimed at investigating the association between the GSTP1 gene polymorphism and T2DM and to clarify their effect on the glycemic control parameters.

Material and methods: From the Egyptian population, we enrolled 112 T2DM patients and 188 healthy controls matched for age, sex and origin. Serum lipid profile, blood-glucose level, glycated hemoglobin $\left(\mathrm{HbA}_{1 \mathrm{c}}\right)$ and body mass index (BMI) were measured. DNA was extracted from the blood samples. Polymerase chain reaction-restriction fragment length polymorphism (PCR-RFLP) was used to measure GSTP1 Ile ${ }^{105} \mathrm{Val}$ gene polymorphism of study participants.

Results: The frequency of the Val allele in exon 5 of the GSTP1 gene in patients with T2DM was higher than that observed in healthy controls (15.2\% vs. 9.6\%); the difference was considered statistically significant when compared to lle allele carriers $(p=0.03)$. The presence of the GSTP1 heterozygous mutant allele Ile/Val was more common in subjects with T2DM than in the control group (30.4\% and $19.2 \%$, respectively; $p=0.02$ ). Variation in the GSTP1 gene was associated with $\mathrm{BMI}(p=0.02)$ and not associated with glycemic control parameters (fasting serum glucose and $\mathrm{HbA}_{1 \mathrm{c}}$ ) or smoking-related risk of T2DM.

Conclusions: GSTP1 gene polymorphism may play a significant role in increasing the susceptibility to and risk of T2DM and obesity regardless of smoking status and had no apparent effect on $\mathrm{HbA}_{1 c}$ in patients with diabetes mellitus.

Key words: GSTP1, type 2 diabetes mellitus, glycated hemoglobin, body mass index, polymerase chain reaction-restriction fragment length polymorphism.

\section{Introduction}

Type 2 diabetes mellitus (T2DM) represents a significant global health problem. It is estimated that six people die every minute from the disease worldwide, a figure that will soon make the disease one of the world's most prevalent causes of preventable mortality [1].

Reactive oxygen species (ROS) production induced by chronic hyperglycemia is implicated as a potential molecular mechanism behind diabetic vascular

\author{
Corresponding author: \\ Maivel H. Ghattas MD, PhD \\ Department of Medical \\ Biochemistry \\ Faculty of Medicine \\ Suez Canal University \\ Ismailia, Egypt \\ E-mail: \\ m_gattas@hotmail.com
}


complications. The ROS activates protein kinase $C$ (PKC) and increases the production of advanced glycation end products (AGEs), leading to superoxide generation [2], which triggers atherosclerosis [3]. Pancreatic $\beta$-cells express low levels of anti-oxidant enzymes and become sensitive to cytotoxic stress that leads to higher risk of oxidative damage $[4,5]$.

Glutathione S-transferases (GSTs) belong to a group of multigene and multifunctional detoxification enzymes, which defend cells against a wide variety of toxic insults from chemicals, metabolites, and oxidative stress [6]. An important condition affecting GST expression is oxidative stress, usually observed in diabetes.

The gene expressing GST enzymes is polymorphic and therefore it is possible that individual variations in metabolic activities of each enzyme may regulate the clearance of toxic DNA intermediates and may be partially responsible for individual host susceptibility to oxidative stress damage of $\beta$-cells [7]. The GSTs comprise a class of enzymes that detoxify tobacco-related carcinogens by conjugating glutathione to facilitate their removal [8].

Improved glycemic control in people with diabetes reduces the risk of long-term complications. The Diabetes Control and Complications Trial [9] and the United Kingdom Prospective Diabetes Study [10] provided evidence for the benefits of tight and sustained glycemic control among type 1 and 2 diabetic patients. Chronic hyperglycemia confers increased risk for long-term diabetes-associated complications and repeated hemoglobin $\mathrm{A}_{1 \mathrm{c}}\left(\mathrm{HbA}_{1 c}\right)$ measures are a widely used marker for glycemic control in diabetes treatment and follow-up [11].

A GSTP1 variant with A to $G$ transition in exon 5 at codon 105 leads to 11 e $^{105} \mathrm{Val}$ amino acid substitution, which reduces the ability to conjugate reactive electrophiles with glutathione and may therefore sensitize cells to free radical-mediated damage. The Val105 variant has been associated with susceptibility to smoking-related cancer [12] and cardiovascular disease $[13,14]$.

Studies have so far reported contradictory results regarding any association between GSTP1 gene polymorphism and T2DM $[15,16]$. There has been no previous report of its effect on the glycemic control parameters. Thus, we conducted a case-control study in the Egyptian population with age- and sex-matched T2DM to evaluate whether the GSTP1 variants modulate the risk of T2DM patients and to clarify their effect on the glycemic control parameters.

\section{Material and methods}

\section{Subjects}

A total of 112 T2DM patients and a control group of 188 healthy subjects were examined in this study.
Diagnosis of T2DM was based on the American Diabetes Association definition of diabetes [17]. Healthy subjects did not meet the criteria for the diagnosis of diabetes mellitus.

\section{Laboratory measurements}

Venous blood samples were drawn after an overnight fast. $\mathrm{HbA}_{1 \mathrm{c}}$ was measured with an ADVIA 1800 chemistry analyzer (Siemens Healthcare Diagnostics, USA). Fasting serum glucose, serum total cholesterol, HDL cholesterol and triglycerides (TG) were measured by automated enzymatic methods on an Hitachi-912 analyzer; LDL cholesterol was calculated according to the Friedewald formula [18]. Hypertension was defined as systolic blood pressure $(B P) \geq 140 \mathrm{~mm} \mathrm{Hg}$, diastolic BP $\geq 90 \mathrm{~mm} \mathrm{Hg}$ and/or a history of hypertension [19]. Current smoker was defined as a subject who continued to smoke cigarettes regularly.

\section{Study subjects}

All the procedures were carried out according to the principles of the Declaration of Helsinki. The study was approved by the Suez Canal University Research Ethics Committee and all the patients and controls provided written informed consent. Table I summarizes the clinical features of patients and controls.

\section{Determination of genotype at the GSTP1 locus}

Genomic DNA was obtained from peripheral blood samples collected in EDTA tubes. The DNA was extracted using DNA purification kit cat \#1120 (Promega, USA). The assay for the polymorphisms in GSTP1-105 was performed as described previously [20]. Each PCR reaction mixture $(40 \mu \mathrm{l})$ contained 200 ng each of primers P105F (5'-ACC CCA GGG CTC TAT GGG AA-3') and P105R (5'-TGA GGG CAC AAG AAG CCC (T-3'), $100 \mathrm{ng}$ of genomic DNA, $1.5 \mathrm{mM}$ $\mathrm{MgCl}_{2}, 100 \mathrm{mM}$ of each dNTP and $1 \cup$ Taq polymerase (Promega, USA). Initial denaturation was carried out at $95^{\circ} \mathrm{C}$ for $5 \mathrm{~min}$. The reaction involved 30 cycles of incubation at $94^{\circ} \mathrm{C}(30 \mathrm{~s}), 55^{\circ} \mathrm{C}(30 \mathrm{~s})$, and $72^{\circ} \mathrm{C}(30 \mathrm{~s})$. A final polymerization step of $72^{\circ} \mathrm{C}$ for 5 min was carried out to complete the elongation processes. After the confirmation of an amplified fragment of the expected size (176 bp) on an agarose gel, the PCR products were digested with $5 \mathrm{U}$ of restriction enzyme Alw261 (Fermentas, UK) in a total volume of $25 \mu \mathrm{l}$. DNA fragments were submitted to electrophoresis through a 3.5\% agarose gel and stained with ethidium bromide $(10 \mathrm{mg} / \mathrm{ml})$.

\section{Statistical analysis}

All data was entered, independently verified and analyzed using SPSS Statistics 17.0. Chi-squared statistics were performed to assess differences 
Table I. General characteristics of the study population

\begin{tabular}{|lccc|}
\hline Variable & Control $(n=188)$ & T2DM $(n=112)$ & Value of $p$ \\
\hline Age [years] & $48.54 \pm 8.07$ & $48.67 \pm 7.3$ & 0.89 \\
\hline Sex (M/F) & $101 / 87$ & $60 / 52$ & 0.98 \\
\hline FBGL level $[\mathrm{mg} / \mathrm{dll}]$ & $96.16 \pm 8.8$ & $208.5 \pm 95.1$ & $0.0001^{*}$ \\
\hline HbA $_{1 \mathrm{c}}$ & $5 \pm 0.74$ & $9.67 \pm 1.89$ & $0.0001^{*}$ \\
\hline BMI $\left[\mathrm{kg} / \mathrm{m}^{2}\right]$ & $28.23 \pm 3.94$ & $29.42 \pm 4.08$ & $0.013^{*}$ \\
\hline Total cholesterol $[\mathrm{mg} / \mathrm{dl}]$ & $210.33 \pm 85.05$ & $217.69 \pm 46.13$ & 0.39 \\
\hline TG $[\mathrm{mg} / \mathrm{dl}]$ & $151.52 \pm 77.09$ & $168.56 \pm 89.45$ & 0.82 \\
\hline HDL-C [mg/dl] & $46.91 \pm 11.19$ & $45.16 \pm 10.78$ & 0.18 \\
\hline VLDL-C [mg/dl] & $30.3 \pm 15.42$ & $33.7 \pm 17.89$ & 0.08 \\
\hline LDL-C [mg/dl] & $133.11 \pm 85.62$ & $138.82 \pm 47.45$ & 0.52 \\
\hline Current smoking (+/-) & $35 / 153$ & $28 / 84$ & 0.89 \\
\hline Systolic BP [mm Hg] & $120.29 \pm 15.52$ & $142.99 \pm 25.34$ & $0.0001^{*}$ \\
\hline Diastolic BP [mm Hg] & $75.13 \pm 8.03$ & $83.21 \pm 12.23$ & $0.0001^{*}$ \\
\hline
\end{tabular}

$F B G L$ - fasting blood glucose level [mg/dl]. Comparisons were performed by Student t-test and $\chi^{2}$ test; data are mean $\pm S D$. *Significant differences between groups $(p<0.05)$

between case and control populations in relation to non-continuous variables. Student's t-test was used to test differences based on continuous variables.

\section{Results}

A total of 300 subjects were enrolled in this study (112 T2DM patients and 188 gender- and agematched controls). The basic demographic data, including body mass index (BMI), age, gender and clinical characteristics of the study populations are summarized in Table I. No significant difference was found between patients and controls in age (45.67 \pm 7.3 vs. $48.54 \pm 8.07$ ) or gender (male: female ratio $=60: 52$ vs. $101: 87$ ) respectively. In diabetics the established risk factors (hypertension, $\mathrm{BMI}, \mathrm{HbA}_{1 \mathrm{c}}$ and fasting blood glucose level) for diabetes were higher than in control subjects. On the other hand, no significant difference in the lipid profiles was observed among the studied groups.

\section{GSTP1 alleles in the two groups}

There was no deviation in the distribution of GSTP1 exon 5 polymorphism genotypes from Hardy-Weinberg equilibrium in the groups studied. The results of exon 5 variants of GSTP1 evaluated by comparing the T2DM group with controls are listed in Table II.

The $\mathrm{G}$ allele ( $\mathrm{Val}$ ) was more prevalent among patients (15.2\%) than among control subjects (9.6\%) ( $p=0.03$ ). We found that $30.4 \%$ of the diabetic patients and $19.2 \%$ of the control subjects were heterozygous for the $\mathrm{G}$ allele (lle/Val) $(p=0.02)$ and $\mathrm{G}$ allele homozygosity (Val/Val) could not be detect- ed in any of the control subjects or the patients. Compared with the lle/lle genotype, subjects with the lle/Val genotype had an elevated risk of type 2 diabetes mellitus $(\mathrm{OR}=1.84,95 \% \mathrm{Cl}=1.07-3.17)$. The risk was increased with the $G$ allele frequency $(p=0.03)$ (Figure 1).

\section{Clinical and functional characteristics in relation to GSTP1 genotypes}

The correlation between different genotypes of exon 5 of the GSTP1 gene with clinical and functional parameters is presented in Table III. We found no statistically significant interactions between GSTP1 genotypes and the age of onset of diabetes $(p=0.27)$. There was no significant influence of these genotypes on lipid profile, smoking or blood pressure. On the other hand, there was a significant influence of these genotypes on BMI $(p=0.02)$.

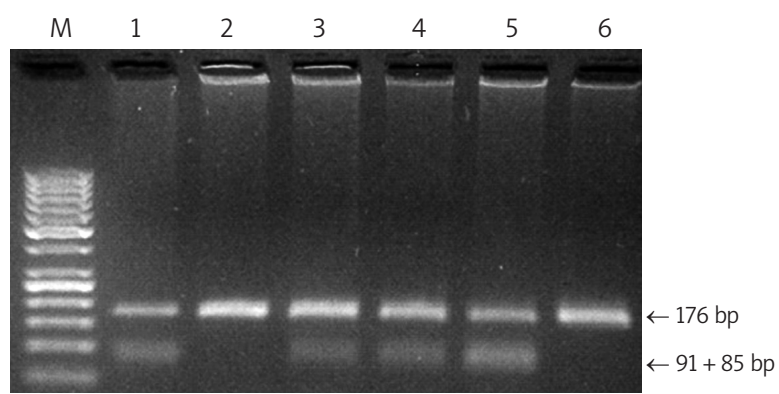

Figure 1. Genotyping of GSTP1 lle ${ }^{105} \mathrm{Val}$ by PCR-RFLP on $3.5 \%$ agarose gel, which distinguishes between the GSTP1 genotypes: A/A (lle/lle) - lines 2 and 6 (176 bp); A/G (lle/Val) - lines 1 and 3-5 (176, 91 and 85 bp) 
Table II. Frequencies and genotype distribution of GSTP1 gene A/G polymorphism in control and type II diabetic patients

\begin{tabular}{|c|c|c|c|c|c|c|}
\hline GSTP1 gene & $\begin{array}{c}\text { Control, } n(\%), \\
n=188\end{array}$ & $\begin{array}{c}\text { T2DM, } n(\%), \\
n=112\end{array}$ & $\chi^{2}$ & Value of $p$ & OR & $95 \% \mathrm{Cl}$ \\
\hline A allele (Ile) & $340(90.4)$ & $190(84.8)$ & & & & \\
\hline G allele (Val) & $36(9.6)$ & $34(15.2)$ & 4.27 & $0.03^{*}$ & 1.69 & $1.024-2.78$ \\
\hline AA (Ile/lle) & $152(80.8)$ & $78(69.6)$ & & & & \\
\hline AG (Ile/Val) & 36 (19.2) & $34(30.4)$ & 4.92 & $0.02^{*}$ & 1.84 & $1.07-3.17$ \\
\hline GG (Val/Val) & $0(0)$ & $0(0)$ & & & & \\
\hline
\end{tabular}

Table III. The relationship between GSTP1 genotypes with different clinical parameters in diabetic patients

\begin{tabular}{|lccc|}
\hline Variables & Carriers of AA $(n=78)$ & Carriers of AG $(n=34)$ & Value of $p$ \\
\hline Onset age [years] & $5.17 \pm 2.05$ & $5.62 \pm 1.84$ & 0.27 \\
\hline Sex $(\mathrm{M} / \mathrm{F})$ & $33 / 45$ & $12 / 22$ & 0.49 \\
\hline $\mathrm{FBGL}$ & $207.38 \pm 23.93$ & $211.08 \pm 99.06$ & 0.85 \\
\hline $\mathrm{HbA}{ }_{1 \mathrm{C}}[\%]$ & $9.7 \pm 1.96$ & $9.59 \pm 1.77$ & 0.78 \\
\hline $\mathrm{BMl}$ & $28.83 \pm 4.21$ & $30.76 \pm 3.47$ & $0.02^{*}$ \\
\hline Total cholesterol $[\mathrm{mg} / \mathrm{dl}]$ & $214.03 \pm 45.77$ & $226.12 \pm 46.5$ & 0.2 \\
\hline TG $[\mathrm{mg} / \mathrm{dl}]$ & $174.13 \pm 92.02$ & $155 \pm 79 \pm 83.18$ & 0.32 \\
\hline $\mathrm{HDL}-\mathrm{C}[\mathrm{mg} / \mathrm{dl}]$ & $45.56 \pm 11.65$ & $44.24 \pm 8.52$ & 0.55 \\
\hline VLDL-C [mg/dl] & $34.83 \pm 18.4$ & $31.16 \pm 16.64$ & 0.32 \\
\hline LDL-C [mg/dl] & $133.64 \pm 47.05$ & $150.72 \pm 46.88$ & 0.08 \\
\hline Current smoking $(+/-)$ & $20 / 58$ & $8 / 26$ & 0.81 \\
\hline Systolic BP & $144.74 \pm 23.93$ & $138.97 \pm 28.28$ & 0.27 \\
\hline Diastolic BP & $82.82 \pm 11.83$ & $84.12 \pm 13.23$ & 0.6 \\
\hline Comparisons were performed by Student-t test and $\chi^{2}$ test. data are mean \pm SD. *Significant differences between groups (p<0.05)
\end{tabular}

Comparisons were performed by Student- $t$ test and $\chi^{2}$ test; data are mean $\pm S D$. ${ }^{\star}$ Significant differences between groups $(p<0.05)$

The association of polymorphism in GSTP1 with glycemic control parameters of diabetes mellitus

Diabetic control is expressed by glycated hemoglobin $\left(\mathrm{HbA}_{1 \mathrm{c}}\right)$ and fasting serum glucose level. No effect of polymorphism in the GSTP1 gene on glycemic control parameters was found. Glycated hemoglobin was $9.59 \pm 1.77$ in lle/Val genotype of the GSTP1 gene and $9.7 \pm 1.96$ in lle/lle genotype of the GSTP1 gene, with $p=0.78$.

\section{Discussion}

Oxidative stress has been considered to be a common pathogenic factor in diabetes and its complications [21]. The family of GST genes plays an important role in protecting cells from oxidative stress. GSTP1 catalyses the detoxification of products arising from DNA oxidation [22]. A defect in detoxifying reactive oxygen species, which is genetically determined, may influence the development and severity of diabetes mellitus [16].
There are many studies dealing with GSTP1 polymorphism in various diseases, but only a few studies have addressed the role of GSTP1 gene polymorphism in diabetes. Therefore, the current study was designed to investigate the role of GST-P1 (lle $\left.{ }^{105} \mathrm{Val}\right)$ gene polymorphism in T2DM patients and healthy controls and whether this variant modulates the glycemic control in Egyptian patients with T2DM.

Our results demonstrate that the frequency of the $\mathrm{G}$ allele was higher in the diabetics compared to controls $(\mathrm{OR}=1.69,95 \% \mathrm{Cl}=1.024-2.78$, $p=0.03$ ). Additionally, significant differences in the frequencies of the Ile/Val genotype between patients and the control group were observed ( $30.4 \%$ vs. $19.2 \%$ respectively). We therefore suggest that the $\mathrm{G}$ allele (Val) of GSTP1 lle ${ }^{105} \mathrm{Val}$ plays an important role in predisposition to T2DM.

There have been controversial results regarding the association between GSTP1 Ile ${ }^{105} \mathrm{Val}$ gene polymorphism and diabetes development. We are in agreement with Ramprasath et al. [15] and Bid et al. [23], who demonstrated that the GSTP1 G allele 
(Val) and its variant genotype (II/Val) play a vital role in the development of diabetes mellitus. In contrast, Yalin et al. [16] and Oniki et al. [24] suggested that GSTP1 Ile105Val polymorphism may not play a significant role in the etiopathogeneses of DM in the Turkish population and Japanese population respectively. These inconsistent data could be explained by ethnic differences in the selected study groups [25].

To investigate the association between GSTP1 Ile ${ }^{105} \mathrm{Val}$ gene polymorphism and glycemic control in relation to $T 2 D M$ we evaluated $\mathrm{HbA}_{1 \mathrm{c}}$ and serum glucose levels in different genotypes. No association between the gene polymorphism and glycemic control parameters in T2DM patients was detected. To our knowledge, this study is the first attempt to evaluate the effect of the GSTP1 genotypes with regard to glycemic control parameters in T2DM.

The epidemic of T2DM observed in recent years is a clear indication of the importance of environmental factors in diabetes onset, in particular obesity and physical inactivity [23]. Obesity, mainly when fat is distributed predominantly at the abdominal level, is the main risk factor for T2DM. Our study is probably the first study to show that GSTP1 heterozygosity (lle/Val) is significantly associated with BMI.

Dyslipidemia observed in T2DM is one of the major factors contributing to vascular risk [26]. In the current study, we further investigated the effect of the genotypes on the lipid profile. There was no association between the genotypes and lipid profile in diabetic patients. This data are consistent with the previous reports which demonstrated that there was no association between GSTP1 genotypes and blood lipids in T2DM patients [15, 23].

GSTP1 detoxifies cigarette smoke-derived toxins and endogenously derived reactive oxygen species. Therefore, it is conceivable that genetic polymorphism in GSTP1 may have an effect on smoking-related risk in T2DM. Concerning the relation to smoking status, previous report showed that active smoking is associated with an increased risk of T2DM [27]. We found that GSTP1 polymorphism was not significantly linked with smoking in T2DM patients. These data are in accordance with Oniki et al. [24].

In conclusion, this is the first study to determine the association of type 2 diabetes with GSTP1 Ile105Val gene polymorphism in the Egyptian population and its effect on glycemic control parameters. These results show that GSTP1 lle/Val genotype may play a significant role in the etiopathogeneses of T2DM, and the GSTP1 gene may be a useful marker in the prediction of T2DM susceptibility of the Egyptian population regardless of smoking status. Our findings suggest that the GSTP1 gene polymorphism had no apparent effect on glycemic control in type 2 diabetes patients; meanwhile, there was a significant correlation with BMI in diabetics. Although some of our data were statistically significant, we acknowledge that the findings presented here are preliminary because of the small number of subjects and that the study requires confirmation in a separate, larger cohort. Additionally, a wide epidemiological study is needed to test the possible association between genotypic and phenotypic effects of other GST gene polymorphisms in diabetic patients.

\section{References}

1. Wild S, Roglic G, Green A, Sicree R, King H. Global prevalence of diabetes: estimates for the year 2000 and projections for 2030. Diabetes Care 2004; 27: 1047-53.

2. Wautier MP, Chappey O, Corda S, Stern DM, Schmidt AM, Wautier JL. Activation of NADPH oxidase by AGE links oxidant stress to altered gene expression via RAGE. Am J Physiol Endocrinol Metab 2001; 280: 685-94.

3. Creager MA, Lüscher TF, Cosentino F, Beckman JA. Diabetes and vascular disease: pathophysiology, clinical consequences and medical therapy: part I. Circulation 2003; 108: 1527-32.

4. Tiedge M, Lortz S, Drinkgern J, Lenzen S. Relation between antioxidant enzyme gene expression and antioxidative defense status of insulin-producing cells. Diabetes 1997; 46: 1733-42.

5. Robertson RP, Harmon J, Tran PO, Tanaka Y, Takahashi H. Glucose toxicity in beta-cells: type 2 diabetes, good radicals gone bad, and the glutathione connection. Diabetes 2003; 52: 581-7.

6. Chasseaud LF. The role of glutathione and glutathione S-transferases in the metabolism of chemical carcinogens and other electrophilic agents. Adv Cancer Res 1979; 29: 175-274.

7. Wang G, Zhang L, Li Q. Genetic polymorphisms of GSTT1, GSTM1, and NQO1 genes and diabetes mellitus risk in Chinese population. Biochem Biophys Res Commun 2006; 341: 310-3.

8. Mao GE, Morris G, Lu QY, et al. Glutathione S-transferase P1 Ile105Val polymorphism, cigarette smoking and prostate cancer. Cancer Detect Prev 2004; 28: 368-74.

9. The Diabetes Control and Complications Trial Research Group. The effect of intensive treatment of diabetes on the development and progression of long-term complications in insulin-dependent diabetes mellitus. N Engl J Med 1993; 329: 977-86.

10. UK Prospective Diabetes Study (UKPDS) Group. Intensive blood-glucose control with sulphonylureas or insulin compared with conventional treatment and risk of complications in patients with type 2 diabetes (UKPDS 33). Lancet 1998; 352: 837-53.

11. Hertel JK, Johansson S, Ræder H, et al. Evaluation of four novel genetic variants affecting hemoglobin A1c levels in a population-based type 2 diabetes cohort (the HUNT2 study). BMC Med Genet 2011; 12: 20.

12. Miller DP, Neuberg D, de Vivo I, et al. Smoking and the risk of lung cancer: susceptibility with GSTP1 polymorphisms. Epidemiology 2003; 14: 545-51.

13. Park JH, El Sohemy A, Cornelis MC, Kim HA, Kim SY, Bae SC. Glutathione S-transferase M1, T1, and P1 gene polymorphisms and carotid atherosclerosis in Korean patients with rheumatoid arthritis. Rheumatol Int 2004; 24: 157-63. 
14. Palmer CN, Young V, Ho M, Doney A, Belch JJ. Association of common variation in glutathione $\mathrm{S}$-transferase genes with premature development of cardiovascular disease in patients with systemic sclerosis. Arthritis Rheum 2003; 48: 854-5.

15. Ramprasath $T$, Senthil Murugan $P$, Prabakaran AD, Gomathi P, Rathinavel A, Selvam GS. Potential risk modifications of GSTT1, GSTM1 and GSTP1 (glutathione$S$-transferases) variants and their association to CAD in patients with type- 2 diabetes. Biochem Biophys Res Commun 2011; 407: 49-53.

16. Yalin S, Hatungil R, Tamer L, et al. Glutathione S-transferase gene polymorphisms in Turkish patients with diabetes mellitus. Cell Biochem Funct 2007; 25: 509-13.

17. American Diabetes Association. Diagnosis and Classification of Diabetes Mellitus. Diabetes Care 2007; 30: S42-7.

18. Friedewald WT, Levy RI, Fredrickson DS. Estimation of the concentration of low-density lipoprotein cholesterol in plasma, without use of the preparative ultracentrifuge. Clin Chem 1972; 18: 499-502.

19. Chobanian AV, Bakris GL, Black HR, et al; National Heart, Lung, and Blood Institute Joint National Committee on Prevention, Detection, Evaluation, and Treatment of High Blood Pressure; National High Blood Pressure Education Program Coordinating Committee. The Seventh Report of the Joint National Committee on Prevention, Detection, Evaluation, and Treatment of High Blood Pressure: the JNC 7 report. JAMA 2003; 289: 2560-72.

20. Harries LW, Stubbins MJ, Forman D, Howard GC, Wolf CR. Identification of genetic polymorphisms at the glutathione S-transferase pi locus and association with susceptibility to bladder, testicular and prostate cancer. Carcinogenesis 1997; 18: 641-4.

21. Lehmann R, Schleicher ED. Molecular mechanisms of diabetic nephropathy. Clin Chim Acta 2000; 297: 135-44.

22. Hayes JD, Pulford DJ. The glutathione S-transferase supergene family: regulation of GST and the contribution of the isoenzymes to cancer chemoprotection and drug resistance. Crit Rev Biochem Mol Biol 1995; 30: 445-600.

23. Bid HK, Konwar R, Saxena M, Chaudhari P, Agrawal CG, Banerjee M. Association of glutathione S-transferase (GSTM1, T1 and P1) gene polymorphisms with type 2 diabetes mellitus in north Indian population. J Postgrad Med 2010; 56: 176-81.

24. Oniki $\mathrm{K}$, Umemoto $\mathrm{Y}$, Nagata $\mathrm{R}$, et al. Glutathione S-transferase A1 polymorphism as a risk factor for smoking-related type 2 diabetes among Japanese. Toxicol Lett 2008; 178: 143-5.

25. Alshagga MA, Mohamed N, Suhid AN, Ibrahim IA, Zakaria SZS. Frequencies of glutathione s-transferase (GSTM1, GSTM3 AND GSTT1) polymorphisms in a Malaysian population. Arch Med Sci 2011; 7: 572-8.

26. Turner RC, Millns H, Neil HA, et al. Risk factors for coronary artery disease in non-insulin dependent diabetes mellitus: United kingdom prospective diabetes study (UKPDS: 23). BMJ 1998; 316: 823-8.

27. Willi, C, Bodenmann, P, Ghali WA, Faris PD, Cornuz J. Active smoking and the risk of type 2 diabetes: a systematic review and meta-analysis. JAMA 2007; 298: 2654-64. 